Fixed Point Theory, 21(2020), No. 1, 167-180

DOI: $10.24193 /$ fpt-ro.2020.1.12

http://www.math.ubbcluj.ro/ nodeacj/sfptcj.html

\title{
A STRONG CONVERGENCE THEOREM FOR FINITE FAMILIES OF BREGMAN QUASI-NONEXPANSIVE AND MONOTONE MAPPINGS IN BANACH SPACES
}

\author{
ENYINNAYA EKUMA-OKEREKE* AND ABIODUN TINUOYE OLADIPO** \\ * Department of Mathematics/Computer Science, Federal University of Petroleum Resources, \\ Effurun, P.M.B 1221, Nigeria \\ E-mail: ekuma.okereke@fupre.edu.ng \\ ** Department of Pure and Applied Mathematics, Ladoke Akintola University of Technology, \\ Ogbomoso, P.M.B 4000, Nigeria
}

Abstract. We introduce a new iterative scheme and prove a strong convergence theorem for it. This iterative scheme finds a common point in the set of fixed points of a finite family of Bregman quasi-nonexpansive mappings and the common solution set of the variational inequality problem for continuous monotone mappings.

Key Words and Phrases: Bregman quasi-nonexpansive mappings, strong convergence, continuous monotone mappings, fixed point.

2010 Mathematics Subject Classification: 47H09, 47H10, 47J25, 47H05, 4705.

Acknowledgement. The authors are grateful to the referees for their careful reading and suggestions.

\section{REFERENCES}

[1] M.A. Alghamdi, N. Shahzad, H. Zegeye, Strong convergence theorems for quasi-Bregman nonexpansive mappings in reflexive Banach spaces, J. Applied Math., 2014(2014), Art. ID 8580686.

[2] M.A. Alghamdi, N. Shahzad, H. Zegeye, Fixed points of Bregman relatively nonexpansive mappings and solutions of variational inequality problems, J. Nonlinear Sci. Appl., 9(2016), 25412552.

[3] Y.I. Alber, Metric and generalized projection operators in Banach spaces, properties and application, Lecture Notes in Pure and Appli. Math., (1996), 15-50.

[4] H.H. Bauschke, J.M. Borwein, P.L. Combettes, Essential smoothness essential strict convexity and legendre functions in Banach spaces, Commun. Contemporary Math., 3(2001), 615-647.

[5] H.H. Bauschke, J.M. Borwein, P.L. Combettes, Bregman monotone optimization algorithms, SIAM J. Control and Optimization, 42(2)(2003), 596-636.

[6] J.F. Bonnas, A. Shapiro, Perturbation Analysis of Optimization Problems, Springer, New York, 2000.

[7] Y. Censor, A. Gibali, S. Reich, The subgradient extragradient method for solving variational inequalities in Hilbert spaces, J. Optim. Theory Appl., 148(2011), 218-335.

[8] L.M. Bregman, The relaxation method for finding the common point of convex sets and its application to the solution of problems in convex programming, USSR Computational Mathematics and Mathematical Physics, 7(1967), 200-217. 
[9] D. Butnariu, A.N. Iusem, Totally Convex Functions for Fixed Points Computation and Infinite Dimensional Optimization, Kluwer Academic, Dordrecht, 2000.

[10] D. Butnariu, S. Reich, A.J. Zaslavski, There are many totally convex functions, J. Convex Anal., 13(2006), 623-632.

[11] D. Butnariu, E. Resmerita, Bregman distances, totally convex functions and a method for solving operator equations in Banach spaces, Abstr. Appl. Anal., 2006(2006), 1-39.

[12] Y. Censor, A. Lent, An iterative row-action method for interval convex programming, J. Optim. Theory Appl., 34(1981), 321-353.

[13] G.Z. Eskandani, M. Raeisi, A new algorithm for finding fixed points of Bregman quasinonexpansive mappings and zeros of maximal monotone operators by using products of resolvents, Results. Math., 71(2017).

[14] A. Gibali, S. Reich, R. Zalas, Outer approximation method for solving variational inequalities in Hilbert space, Optimization, 66(2017), 417-437.

[15] H. Iiduka, W. Takahashi, Strong convergence theorems for nonexpansive mappings and inversestrongly monotone mappings, Nonlinear Anal., 61(2005), 341-350.

[16] D. Kinderlehrer, G. Stampacchia, An Introduction to Variational Inequalities and Their Applications, Academic Press, New York, 1980.

[17] F. Kohsaka, W. Takahashi, Proximal point algorithms with Bregman functions in Banach spaces, J. Nonlinear Convex Anal., 5(2005), 505-523.

[18] G.M. Korpelevich, An extragradient method for finding saddle points and for other problems, Ekonomika I Matematicheskie Metody, 12(1976), 747-756.

[19] P.E. Maingé, Strong convergence of projected subgradient methods for nonsmooth and nonstrictly convex minimization, Set Valued Analysis, 16(7-8)(2008), 899-912.

[20] V. Martin-Marquez, S. Reich, S. Sabach, Bregman strongly nonexpansive operators in reflexive Banach spaces, J. Math. Anal. Appl., 400(2013), 597-614.

[21] E. Naraghirad, J.C. Yao, Bregman weak relatively nonexpansive mappings in Banach spaces, Fixed Point Theory Appl., 141(2013), https://doi.org/10.1186/1687-1812-2013-141.

[22] A.T. Oladipo, E. Ekuma-Okereke, An iterative algorithm for a common fixed point of Bregman relatively nonexpansive mappings, axXiv: 1707.08379 [Math FA].

[23] R.P. Phelps, Convex Functions, Monotone Operators and Differentiability, Springer, Berlin, 1993.

[24] D. Reem, S. Reich, Solutions to inexact resolvent inclusion problems with applications to nonlinear analysis and optimization, Rend. Circ. Mat. Palermo, 67(2018), 337-371.

[25] S. Reich, A weak convergence theorem for the alternating method with Bregman distances, in: Theory and Applications of Nonlinear Operators of Accretive and Monotone Type, Marcel Dekker, NewYork (1996), 313-318.

[26] S. Reich, S. Sabach, A strong convergence theorem for a proximal-type algorithm in reflexive Banach spaces, J. Nonlinear Convex Anal., 73(2009), no. 3, 471-485.

[27] S. Reich, S. Sabach, Two strong convergence theorems for a proximal method in reflexive Banach spaces, Numerical Functional Analysis and Optimization, 31(2010), 22-44.

[28] S. Reich, S. Sabach, Two strong convergence theorems for Bregman strongly nonexpansive operators in reflexive Banach spaces, Nonlinear Anal., 73(2010), 122-135.

[29] S. Reich, S. Sabach, Existence and approximation of fixed points of Bregman firmly nonexpansive mappings in reflexive Banach spaces, Fixed Point Algorithms for Inverse Problems in Science and Engineering, 49(2011), 301-316.

[30] R.T. Rockafellar, Convex Analysis, Princeton University Press, Princeton, 1970.

[31] N. Shahzad, A. Udomene, Fixed point solutions of variational inequalities for asymptotically nonexpansive mappings in Banach spaces, Nonlinear Anal. TMA, 64(2006), 558-567.

[32] G.C. Ugwunnadi, B. Ali, Convergence results for a common solution of a finite family of equilibrium problems and quasi-nonexpansive mappings in Banach space, J. Operators, 2016 (2016), Art. ID 580686.

[33] H.K. Xu, Another control condition in an iterative method for nonexpansive mappings, Bull. Australian Math. Soc., 65(2002), no. 1, 109-113.

[34] C. Zălinescu, Convex Analysis in General Vector Spaces, World Scientific, River Edge, NJ, 2002. 
[35] H. Zegeye, N. Shahzad, Strong convergence theorems for monotone mappings and relatively weak nonexpansive mappings, Nonlinear Anal. Theory, Methods Appl., 70(2009), 2707-2716.

[36] H. Zegeye, N. Shahzad, A hybrid approximation method for equilibrium, variational inequality and fixed point problems, Nonlinear Anal. Hybrid Syst., 4(2010), 619-630.

[37] H. Zegeye, N. Shahzad, Approximation of common solution of variational inequality problems for two monotone mappings in Banach spaces, Optim. Lett., 5(2011), 691-704.

[38] H. Zegeye, N. Shahzad, Convergence theorems for a common point of solutions of equilibrium and fixed point of relatively nonexpansive multivalued mapping problems, Abstr. Appl. Anal., 2012(2012), Art. ID 859598.

[39] H. Zegeye, N. Shahzad, A. Alotaibi, Convergence results for a common solution of a finite family of variational inequality problems for monotone mappings with Bregman distance, Fixed Point Theory Appl., 343 (2013). https://doi.org/10.1186/1687-1812-2013-343.

[40] H. Zegeye, N. Shahzad, Y. Yao, Minimum-norm solution of variational inequality and fixed point problem in Banach spaces, Optimization, 64(2015), no. 2, 453-471.

Received: October 26, 2017; Accepted: October 11, 2018. 